九州大学学術情報リポジトリ

Kyushu University Institutional Repository

\title{
Potential of Power Generation by Solar Batteries for Operating Irrigation Pumps in Ishigaki Island
}

Hao, Aimin

Graduate School of Bioresource and Bioenvironmental Sciences, Kyushu University

Marui, Atsushi

Departmetn of Environmetn Science, Kyushu Kyoritsu University

Haraguchi, Tomokazu

Faculty of Agriculture, Saga University

Nakano, Yoshisuke

Faculty of Agriculture, Kyushu University

https://doi.org/10.5109/9265

出版情報: 九州大学大学院農学研究院紀要. 51 (2)，pp.423-430，2006-10-27. Faculty of Agriculture, Kyushu University

バージョン :

権利関係 : 


\title{
Potential of Power Generation by Solar Batteries for Operating Irrigation Pumps in Ishigaki Island
}

\author{
Aimin HAO ${ }^{*}$, Atsushi MARUI ${ }^{2}$, Tomokazu HARAGUCHI ${ }^{3}$ \\ and Yoshisuke NAKANO \\ Laboratory of Irrigation and Water Utilization, Division of Regional Environment Science, \\ Department of Bioproduction Environmental Sciences, Faculty of Agriculture, \\ Kyushu University, Fukuoka 812-8581, Japan \\ (Received June 30, 2006 and accepted July 24, 2006)
}

\begin{abstract}
Electricity generated by solar batteries has many merits. Especially in a small island where there are not enough water resources, adequate and cheap electricity is prerequisite for agriculture. First, trials to estimate electricity generation by solar battery were conducted using the limited data on solar radiation energy. Second, operation times were estimated for various pumps placed in the pumping station in Ishigaki Island. It was clarified that there was a tendency that operation times calculated by estimated curves showed somewhat longer hours that of observed curves, for the smaller pumps. On the other hand, for the larger pumps, there was a tendency that operation times derived from observed curves exceeded the times derived from estimated curves. Third, a simulation was conducted for finding the suitable irrigation area supported by a self electricity generating system. It was concluded that a $15 \mathrm{~kW}$ pump was suitable as this was operated longer hours than other pumps and irrigated area slightly increased if rotation of irrigation was applied for the $200 \mathrm{kWp}$ system. But for the $1000 \mathrm{kWp}$ system, irrigated area increased effectively.
\end{abstract}

\section{INTRODUCTION}

Electricity is used for agriculture not only to deliver irrigation water but also to control valves, heater, cooler and so on. To lessen the expenses for electricity, it is required to develop new energy for supporting the farmers. Electricity generated by solar batteries has many merits. First, the solar energy resource is enormous. Second, electricity is generated by a solar battery which has no mechanical parts with noisy sound. Third, no substances are generated which pollutes the environment. Fourth, the power generation system can be controlled automatically. Fifth, the system can be placed in anywhere there is open area suitable for construction. Sixth, amount of electricity generation can be increased easily with installing additional modules. Seventh, price of modules will become cheaper by mass production. Eighth, not only direct solar radiation but also diffused radiation is effective for generating electricity. On the other hand, some demerits are existing. First, amount of generation is affected by climate conditions and season. Second, intensity of solar energy is $1.0 \mathrm{~kW} / \mathrm{m}^{2}$ in maximum. Third, the system to convert direct current to alternating current is necessary. Fourth, a buttery as an electricity pond is expensive. Fifth, the wide open space for constructing of the system is required if the

${ }^{1}$ Laboratory of Irrigation and Water Utilization, Division of Regional Environment Science, Department of Bioproduction Environmental Sciences, Graduate School of Bioresource and Bioenvironmental Sciences, Kyushu University

${ }^{2}$ Department of Environment Science, Kyushu Kyoritsu University

${ }^{3}$ Laboratory of Agricultural Water Supply and Management, Department of Agriculture Science, Faculty of Agriculture, Saga University

* Corresponding author (E-mail: aimin@bpes.kyushu-u.ac.jp) facility become larger.

For supply to a pumping station, it is necessary to place the generation system close to the pumping station. If it is far from the pumping station, additional expenses are required to construct the deliver line for the generated electricity. If it is possible to connect with the lines of commercial electricity company, the system can be placed somewhat far from the pumping station.

In this study, some trials were conducted numerically for use of the electricity generated by solar batteries to operate the pumping station in Ishigaki Island.

\section{MATERIALS AND METHODS}

\section{Estimating the diurnal change of solar radiation}

In Ishigaki Island, weather station is providing daily solar radiation data which is prerequisite for evaluating electricity generation. It is required at least hourly changes of solar radiation as the solar radiation changes abruptly affected by the clouds, vapor and dust. In this study, following equation was used for calculating the hourly changes of solar radiation.

$$
I_{h}=\pi \frac{Q}{2 T_{0}} \cos \left(\pi \frac{T-12}{T_{0}}\right)
$$

where $I_{h}$ is solar radiation for one hour $\left(\mathrm{kWh} / \mathrm{m}^{2}\right), Q$ is daily total solar radiation $\left(\mathrm{kWh} / \mathrm{m}^{2}\right), T_{0}$ is potential length daytime of a day (hour), and $T$ is arbitrary time of a day (solar hour).

Figure 1 shows the comparison between observed and calculated amount of diurnal changes of solar radiation on a fine day, cloudy day and rainy day. Though, the height of amplitude of calculated solar radiation was a little lower than the observation on a fine day August 28 , estimation of diurnal change of solar radiation by eq. 

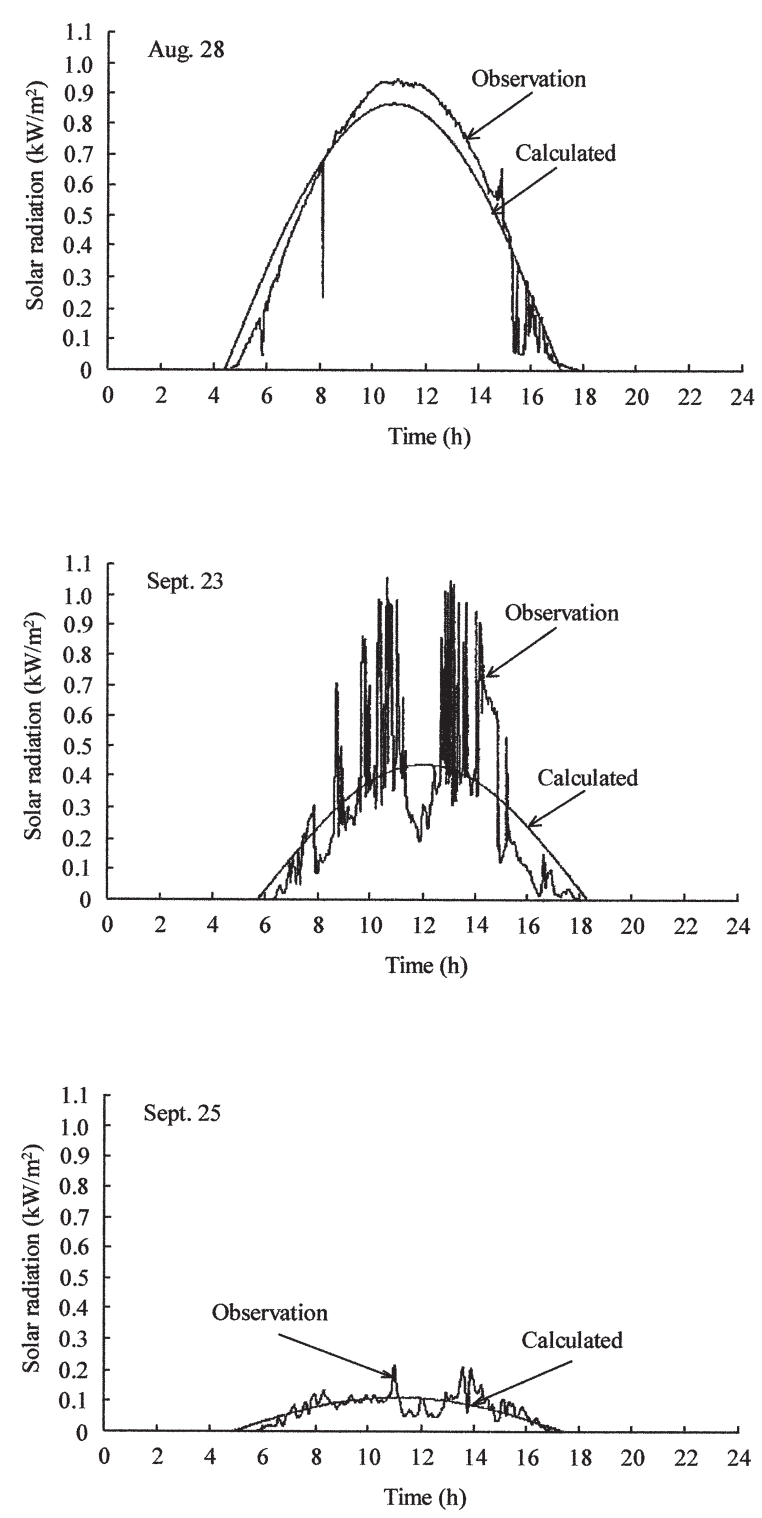

Fig. 1. Comparison of solar radiation between observation and calculation.

(1) was reasonable.

\section{Estimation of electricity generation}

The daily amount of electricity generation can be calculated using following equations.

$$
\begin{aligned}
& P_{a}=Q A K_{t} K_{d} \\
& P=P_{a} P_{d} \eta
\end{aligned}
$$

where, $P_{a}$ is daily amount of electricity generation per unit module $(\mathrm{kWh} / \mathrm{kWp}), A$ is parameter which indicates the area for peak electricity $\left(=1.0 \mathrm{~m}^{2} / \mathrm{kWp}\right), K_{t}$ is coefficient of temperature adjustment $(0.85), K_{d}$ is coefficient of direct current adjustment $(0.85), P_{d}$ is capacity of solar electricity generation module $(\mathrm{kWp})$ and $\eta$ is average coefficient of inverter (0.85).

If the adequate values of coefficient in above equations are substituted, daily amount of electricity generated by the modular capacity of $P_{d}(\mathrm{kWp})$ can be calculated as,

$$
P=0.85^{3} Q P_{d}
$$

Then the amount of hourly electricity generation $P_{t}$ (kWh) can be calculated as,

$$
P_{t}=0.85^{3} P_{d} \pi \frac{Q}{2 T_{0}} \cos \left(\pi \frac{T-12}{T_{0}}\right)
$$

\section{Estimation of operation duration}

Operation duration of a specified pump can be estimated as shown in Figure 2. First, diurnal change of electricity generation is estimated with eq. (5). Second, the starting point $\left(T_{2}\right)$ and ending point $\left(T_{1}\right)$ of operation are estimated from the intersection of pump capacity line and electricity generation curve. Third, operation duration can be estimated by $T_{d}=T_{1}-T_{2}$, as shown in Figure 2.

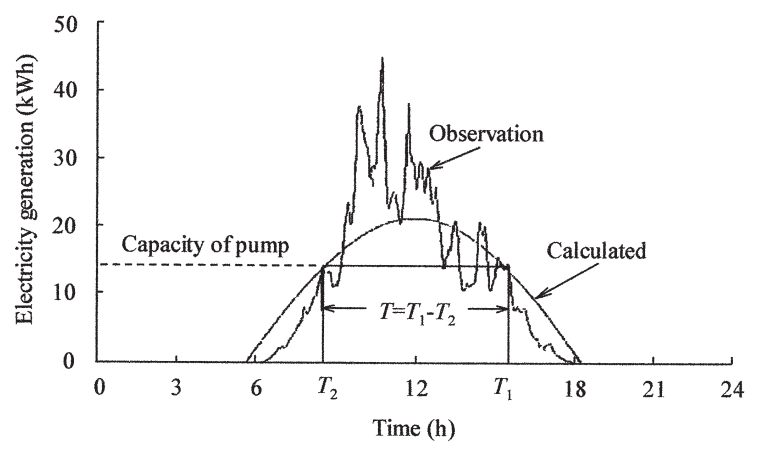

Fig. 2. Operation times of pumps, $T_{d}$.

If a capacity of a pump is assumed as $P_{p}$, starting point and ending point are derived with next equations.

$$
\begin{aligned}
& T_{1}=\frac{T_{0}}{\Pi} \cos ^{-1}\left(\frac{2 T_{0}}{Q} \frac{P_{p}}{0.85^{3} \Pi P_{d}}\right)+12 \\
& T_{2}=-\frac{T_{0}}{\pi} \cos ^{-1}\left(\frac{2 T_{0}}{Q} \frac{P_{p}}{0.85^{3} \Pi P_{d}}\right)+12
\end{aligned}
$$

Subtracting eq. (7) from eq. (6), operation hours can be estimated as,

$$
T_{d}=T_{1}-T_{2}=\frac{2 T_{0}}{\Pi} \cos ^{-1}\left(\frac{2 T_{0}}{Q} \frac{P_{p}}{0.85^{3} \Pi P_{d}}\right)
$$

If actually observed curves are used, operation duration is limited to the times above the line of capacity of a pump. Referring to the Figure 2, actual operation time was considered as about $80 \%$ of the estimation.

\section{Comparison between the actual and estimated operation duration times}

The validity of estimated operation duration times were evaluated comparing the data derived from actual curve and estimated curve. The capacity of a pump was selected as $15 \mathrm{~kW}, 37 \mathrm{~kW}, 95 \mathrm{~kW}, 260 \mathrm{~kW}, 295 \mathrm{~kW}$, $360 \mathrm{~kW}$ and $550 \mathrm{~kW}$, considering the varieties in Ishigaki Island. Solar radiation data observed at every minute were used on the selected 9 days.

Operation duration times calculated from one pump 
Table 1. Operation times of one pump system

(unit: Hours)

\begin{tabular}{|c|c|c|c|c|c|c|c|c|c|c|}
\hline \multirow{2}{*}{ Date } & \multirow{2}{*}{ Weather } & \multirow{2}{*}{ Capacity } & & \multicolumn{7}{|c|}{ Capacity of pumps } \\
\hline & & & & $15 \mathrm{~kW}$ & $37 \mathrm{~kW}$ & $95 \mathrm{~kW}$ & $260 \mathrm{~kW}$ & $285 \mathrm{~kW}$ & $360 \mathrm{~kW}$ & $550 \mathrm{~kW}$ \\
\hline \multirow{4}{*}{$\begin{array}{c}\text { Aug. } \\
28\end{array}$} & \multirow{4}{*}{ Clear } & \multirow{2}{*}{$200 \mathrm{kWp}$} & Obs. & 11.56 & 9.84 & 3.86 & 0 & 0 & 0 & 0 \\
\hline & & & Cal. & 10.35 & 8.95 & 4.85 & 0 & 0 & 0 & 0 \\
\hline & & \multirow{2}{*}{1000 kWp } & Obs. & 12.47 & 12.14 & 11.26 & 8.59 & 8.16 & 6.73 & 0.00 \\
\hline & & & Cal. & 11.95 & 11.12 & 9.93 & 8.32 & 7.97 & 6.82 & 2.60 \\
\hline \multirow{4}{*}{$\begin{array}{c}\text { Aug. } \\
29\end{array}$} & \multirow{4}{*}{ Clear } & \multirow{2}{*}{$200 \mathrm{kWp}$} & Obs. & 11.51 & 9.71 & 3.11 & 0 & 0 & 0 & 0 \\
\hline & & & Cal. & 10.52 & 8.85 & 4.15 & 0 & 0 & 0 & 0 \\
\hline & & \multirow{2}{*}{$1000 \mathrm{kWp}$} & Obs. & 12.46 & 12.12 & 11.19 & 8.40 & 7.93 & 6.40 & 0.00 \\
\hline & & & Cal. & 12.13 & 11.38 & 9.97 & 8.03 & 7.80 & 6.48 & 1.65 \\
\hline \multirow{5}{*}{$\begin{array}{c}\text { Aug. } \\
30\end{array}$} & \multirow{5}{*}{ Clear } & \multirow{2}{*}{$200 \mathrm{kWp}$} & Obs. & 11.38 & 9.35 & 0 & 0 & 0 & 0 & 0 \\
\hline & & & Cal. & 10.38 & 8.20 & 3.05 & 0 & 0 & 0 & 0 \\
\hline & & \multirow{2}{*}{$1000 \mathrm{kWp}$} & Obs. & 12.44 & 12.05 & 11.02 & 7.84 & 7.30 & 5.43 & 0.00 \\
\hline & & & Cal. & 11.58 & 10.75 & 9.93 & 6.78 & 6.35 & 5.18 & 1.47 \\
\hline & & \multirow{2}{*}{$200 \mathrm{kWp}$} & Obs. & 10.46 & 6.70 & 0 & 0 & 0 & 0 & 0 \\
\hline \multirow{3}{*}{$\begin{array}{l}\text { Setp. } \\
23\end{array}$} & \multirow{3}{*}{$\begin{array}{c}\text { Partly } \\
\text { rainy }\end{array}$} & & Cal. & 8.57 & 4.97 & 0.85 & 0 & 0 & 0 & 0 \\
\hline & & \multirow{2}{*}{$1000 \mathrm{kWp}$} & Obs. & 12.26 & 11.60 & 9.84 & 2.58 & 0 & 0 & 0 \\
\hline & & & Cal. & 10.95 & 9.77 & 7.63 & 2.63 & 23.00 & 1.90 & 0.42 \\
\hline \multirow{4}{*}{$\begin{array}{l}\text { Setp. } \\
24\end{array}$} & \multirow{4}{*}{ Rainy } & \multirow{2}{*}{$200 \mathrm{kWp}$} & Obs. & 0 & 0 & 0 & 0 & 0 & 0 & 0 \\
\hline & & & Cal. & 2.50 & 0 & 0 & 0 & 0 & 0 & 0 \\
\hline & & \multirow{2}{*}{$1000 \mathrm{kWp}$} & Obs. & 11.01 & 8.35 & 0 & 0 & 0 & 0 & 0 \\
\hline & & & Cal. & 9.95 & 7.37 & 0.80 & 0 & 0 & 0 & 0 \\
\hline \multirow{4}{*}{$\begin{array}{l}\text { Setp. } \\
25\end{array}$} & & & Obs. & 0 & 0 & 0 & 0 & 0 & 0 & 0 \\
\hline & & $200 \mathrm{kWp}$ & Cal. & 1.37 & 0 & 0 & 0 & 0 & 0 & 0 \\
\hline & Rainy & & Obs. & 10.96 & 8.21 & 0 & 0 & 0 & 0 & 0 \\
\hline & & $1000 \mathrm{kWp}$ & Cal. & 9.90 & 7.45 & 0.52 & 0 & 0 & 0 & 0 \\
\hline & & $200 \mathrm{kWn}$ & Obs. & 9.82 & 4.33 & 0 & 0 & 0 & 0 & 0 \\
\hline Setp. & Cloudv & $200 \mathrm{kWp}$ & Cal. & 8.43 & 3.53 & 0.07 & 0 & 0 & 0 & 0 \\
\hline 26 & Cloudy & $10001-1=$ & Obs. & 12.14 & 11.30 & 9.00 & 0 & 0 & 0 & 0 \\
\hline & & $1000 \mathrm{kWp}$ & Cal. & 10.98 & 9.47 & 7.40 & 1.75 & 1.53 & 0.90 & 0 \\
\hline & & & Obs. & 11.26 & 9.03 & 0 & 0 & 0 & 0 & 0 \\
\hline Setp. & Clear & $200 \mathrm{kWp}$ & Cal. & 10.80 & 10.30 & 8.95 & 6.98 & 6.60 & 5.07 & 0 \\
\hline 27 & clear & & Obs. & 12.41 & 11.99 & 10.86 & 7.33 & 6.70 & 4.44 & 0 \\
\hline & & $1000 \mathrm{kWp}$ & Cal. & 9.23 & 8.12 & 2.38 & 0 & 0 & 0 & 0 \\
\hline & & $200 \mathrm{kWn}$ & Obs. & 6.50 & 0 & 0 & 0 & 0 & 0 & 0 \\
\hline Setp. & Bainy & $200 \mathrm{kWp}$ & Cal. & 4.85 & 0.40 & 0 & 0 & 0 & 0 & 0 \\
\hline & Rainy & & Obs. & 11.57 & 9.87 & 4.01 & 0 & 0 & 0 & 0 \\
\hline & & $1000 \mathrm{kWp}$ & Cal. & 9.45 & 8.35 & 4.10 & 0 & 0 & 0 & 0 \\
\hline
\end{tabular}

Obs.: Obsevation, Cal.: Calculated

system was listed in Table 1 . Operation duration times calculated for two pumps system was listed in Table 2. Second pump was operated in addition to the first pump when there was some residual electricity.

There was a tendency that operation times calculated by estimated curves were somewhat longer than that by actual curves for pumps of smaller capacity. On the other hand, for larger pumps, there was a tendency that operation times derived from observed curves exceeded the operation times derived from estimated curves. Obviously the operation times of two pumps system increased doubly comparing to the one pump system for smaller pumps in the larger electricity generation module. In the smaller electricity generation module, the operation times did not increase even if two pumps system was adopted for larger pumps.

\section{Study site}

Ishigaki Island locates in latitude N24 $20^{\prime \prime}$ and in longitude E124 10" and belongs to the subtropical oceanic climate area. Annual rainfall is $2,072 \mathrm{~mm}$, average air temperature is $23.8^{\circ} \mathrm{C}$ and average relative humidity is $79 \%$.

Main crop productions are sugar cane, pineapple, paddy rice and livestock. There is an irrigation reservoir into which water is mainly supplied by pumping from the lower river. Irrigation water is delivered through a pipe line system to the command area 2,310 ha. Thus electricity is prerequisite for pumping up and pressurizing water to deliver water first to many farm ponds and then to each field.

The price of electricity supplied by an electricity company to a pump station is $40 \%$ cheaper than the city use. Only 16 hours in a day during the night, however, is allowed to use. The pump station have 7 different types of pumps with capacity of $15 \mathrm{~kW}, 37 \mathrm{~kW}, 95 \mathrm{~kW}, 260 \mathrm{~kW}$, $285 \mathrm{~kW}, 360 \mathrm{~kW}$ and $550 \mathrm{~kW}$.

\section{RESULTS AND DISCUSSION}

\section{Annual days of operating pumps}

Two solar energy electricity generation systems different in $P_{d}$, i.e. $200 \mathrm{kWp}$ and $1000 \mathrm{kWp}$, were considered to operate irrigation pumps in Ishigaki Island. Climatic 
Table 2. Operation times of two pump system

(unit: Hours)

\begin{tabular}{|c|c|c|c|c|c|c|c|c|c|c|}
\hline \multirow{2}{*}{ Date } & \multirow{2}{*}{ Weather } & \multirow{2}{*}{ Capacity } & & \multicolumn{7}{|c|}{ Capacity of pumps } \\
\hline & & & & $15 \mathrm{~kW}$ & $37 \mathrm{~kW}$ & $95 \mathrm{~kW}$ & $260 \mathrm{~kW}$ & $285 \mathrm{~kW}$ & $360 \mathrm{~kW}$ & $550 \mathrm{~kW}$ \\
\hline \multirow{4}{*}{$\begin{array}{c}\text { Aug. } \\
28\end{array}$} & \multirow{4}{*}{ Clear } & \multirow{2}{*}{$200 \mathrm{kWp}$} & Obs. & 21.96 & 16.37 & 3.86 & 0 & 0 & 0 & 0 \\
\hline & & & Cal. & 19.80 & 15.57 & 4.85 & 0 & 0 & 0 & 0 \\
\hline & & \multirow{2}{*}{$1000 \mathrm{kWp}$} & Obs. & 24.72 & 23.72 & 21.02 & 10.50 & 8.16 & 6.73 & 0.00 \\
\hline & & & Cal. & 23.48 & 21.52 & 18.81 & 11.84 & 9.75 & 6.82 & 2.60 \\
\hline \multirow{4}{*}{$\begin{array}{c}\text { Aug. } \\
29\end{array}$} & \multirow{4}{*}{ Clear } & \multirow{2}{*}{$200 \mathrm{kWp}$} & Obs. & 21.81 & 15.89 & 3.11 & 0 & 0 & 0 & 0 \\
\hline & & & Cal. & 19.65 & 15.12 & 4.15 & 0 & 0 & 0 & 0 \\
\hline & & \multirow{2}{*}{$1000 \mathrm{kWp}$} & Obs. & 24.69 & 23.64 & 20.82 & 8.40 & 7.93 & 6.40 & 0.00 \\
\hline & & & Cal. & 23.70 & 21.90 & 18.77 & 10.81 & 7.80 & 6.48 & 1.65 \\
\hline \multirow{5}{*}{$\begin{array}{c}\text { Aug. } \\
30\end{array}$} & \multirow{5}{*}{ Clear } & \multirow{2}{*}{$200 \mathrm{kWp}$} & Obs. & 21.39 & 14.49 & 0 & 0 & 0 & 0 & 0 \\
\hline & & & Cal. & 19.08 & 13.13 & 3.03 & 0 & 0 & 0 & 0 \\
\hline & & \multirow{2}{*}{$1000 \mathrm{kWp}$} & Obs. & 24.61 & 23.44 & 20.27 & 7.84 & 7.30 & 5.43 & 0.00 \\
\hline & & & Cal. & 22.45 & 21.13 & 18.03 & 9.05 & 7.53 & 5.18 & 1.47 \\
\hline & & \multirow{2}{*}{$200 \mathrm{kWp}$} & Obs. & 18.47 & 6.70 & 0 & 0 & 0 & 0 & 0 \\
\hline \multirow{3}{*}{$\begin{array}{l}\text { Setp. } \\
23\end{array}$} & \multirow{3}{*}{$\begin{array}{l}\text { Partly } \\
\text { rainy }\end{array}$} & & Cal. & 14.80 & 6.79 & 0.85 & 0 & 0 & 0 & 0 \\
\hline & & \multirow{2}{*}{$1000 \mathrm{kWp}$} & Obs. & 24.07 & 22.09 & 16.34 & 2.58 & 0 & 0 & 0 \\
\hline & & & Cal. & 20.93 & 18.40 & 2.41 & 3.26 & 2.65 & 1.90 & 0.42 \\
\hline \multirow{4}{*}{$\begin{array}{c}\text { Setp. } \\
24\end{array}$} & \multirow{4}{*}{ Rainy } & \multirow{2}{*}{$200 \mathrm{kWp}$} & Obs. & 0 & 0 & 0 & 0 & 0 & 0 & 0 \\
\hline & & & Cal. & 2.50 & 0 & 0 & 0 & 0 & 0 & 0 \\
\hline & & \multirow{2}{*}{$1000 \mathrm{kWp}$} & Obs. & 20.24 & 8.35 & 0 & 0 & 0 & 0 & 0 \\
\hline & & & Cal. & 18.63 & 9.95 & 0.80 & 0 & 0 & 0 & 0 \\
\hline \multirow{4}{*}{$\begin{array}{c}\text { Setp. } \\
25\end{array}$} & & $200 \mathrm{kWn}$ & Obs. & 0 & 0 & 0 & 0 & 0 & 0 & 0 \\
\hline & Rainy & & Cal. & 1.37 & 0 & 0 & 0 & 0 & 0 & 0 \\
\hline & Ramlny & 10001 W & Obs. & 20.09 & 8.21 & 0 & 0 & 0 & 0 & 0 \\
\hline & & $1000 \mathrm{kWp}$ & Cal. & 18.65 & 9.03 & 0.52 & 0 & 0 & 0 & 0 \\
\hline & & $200 \mathrm{kWn}$ & Obs. & 16.28 & 4.33 & 0 & 0 & 0 & 0 & 0 \\
\hline Setp. & Cloudv & $200 \mathrm{kwp}$ & Cal. & 13.16 & 4.36 & 0.07 & 0 & 0 & 0 & 0 \\
\hline & Cloudy & 10001-W/ & Obs. & 23.70 & 21.16 & 12.95 & 0 & 0 & 0 & 0 \\
\hline & & $1000 \mathrm{kWp}$ & Cal. & 20.91 & 18.00 & 10.83 & 1.78 & 1.53 & 0 & 0 \\
\hline & & $200 \mathrm{kWp}$ & Obs. & 21.02 & 13.08 & 0 & 0 & 0 & 0 & 0 \\
\hline $\begin{array}{l}\text { Setp. } \\
27\end{array}$ & Clear & $200 \mathrm{kWp}$ & Cal. & 17.71 & 13.09 & 2.38 & 0 & 0 & 0 & 0 \\
\hline & Clear & $1000 \mathrm{kWn}$ & Obs. & 24.54 & 23.26 & 19.79 & 7.33 & 0 & 0 & 0 \\
\hline & & $1000 \mathrm{KVp}$ & Cal. & 21.18 & 19.63 & 16.97 & 7.15 & 6.60 & 5.07 & 0 \\
\hline & & $200 \mathrm{kWn}$ & Obs. & 6.50 & 0 & 0 & 0 & 0 & 0 & 0 \\
\hline Setp. & Rainy & & Cal. & 5.98 & 0.40 & 0 & 0 & 0 & 0 & 0 \\
\hline & & $1000 \mathrm{kWp}$ & Obs. & 22.00 & 16.47 & 4.01 & 0 & 0 & 0 & 0 \\
\hline & & $1000 \mathrm{KWp}$ & Cal. & 18.02 & 13.35 & 4.37 & 0 & 0 & 0 & 0 \\
\hline
\end{tabular}

Obs.: Obsevation, Cal.: Calculated

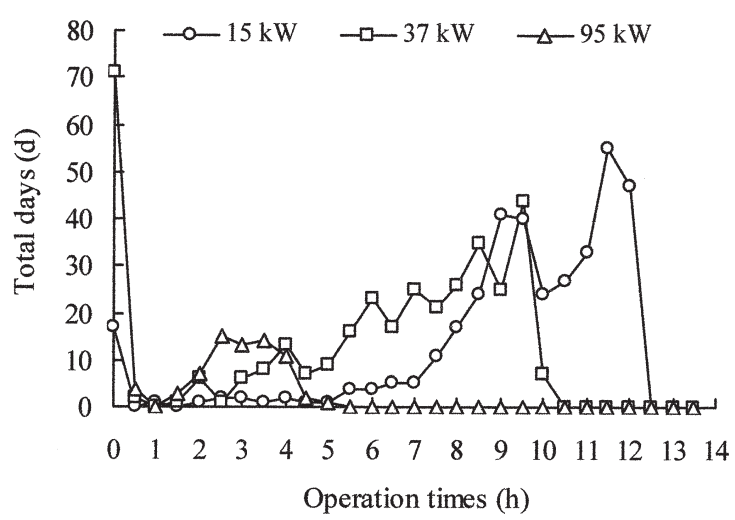

(a) $200 \mathrm{kWp}$

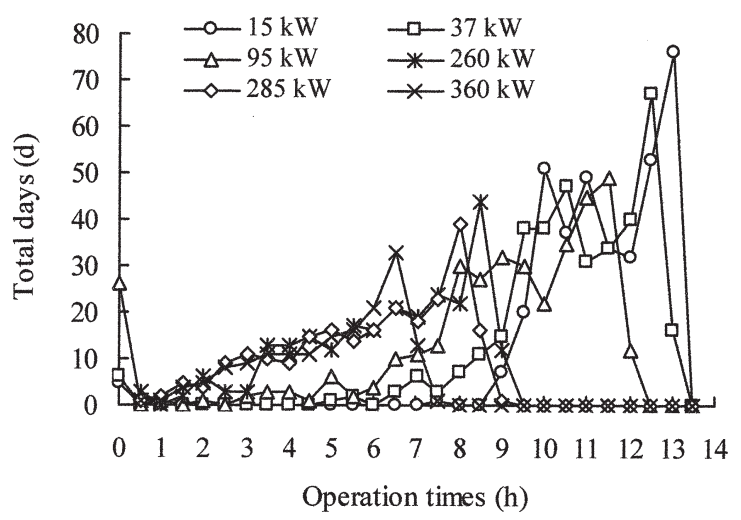

(b) $1000 \mathrm{kWp}$

Fig. 3. Annual total days of operation times for pumps (One pump system).

conditions were referred to the data in 1969 which was used for designing the irrigation project in this area. Figures 3 and 4 show the annual days for daily operation times of each pump capacity in one pump system and two pumps system, respectively.
In the $200 \mathrm{kWp}$ solar battery systems, pumps of $15 \mathrm{~kW}$ and $37 \mathrm{~kW}$ pump capacity were operated frequently. For a $15 \mathrm{~kW}$ pump, annual total days of operation times of 11.5 hours was 55 days (Fig. 3a), and for two $15 \mathrm{~kW}$ pumps, operation times of 20.5 hours was 44 


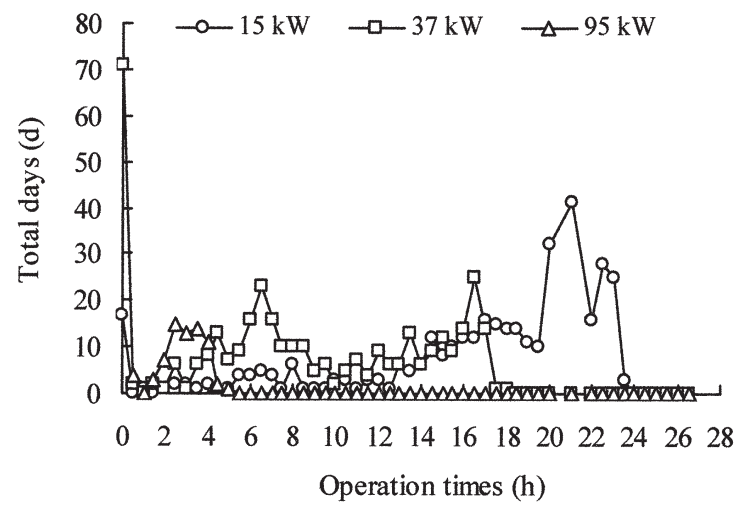

(a) $200 \mathrm{kWp}$

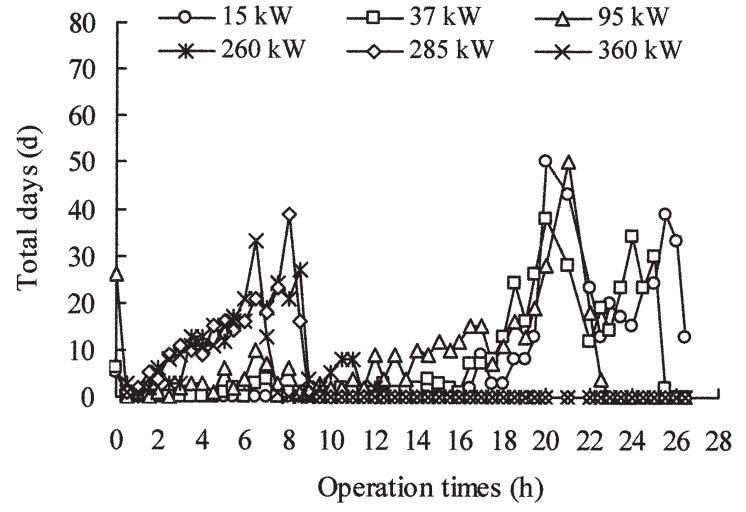

(b) $1000 \mathrm{kWp}$

Fig. 4. Annual total days of operation times for pumps (Two pumps system).

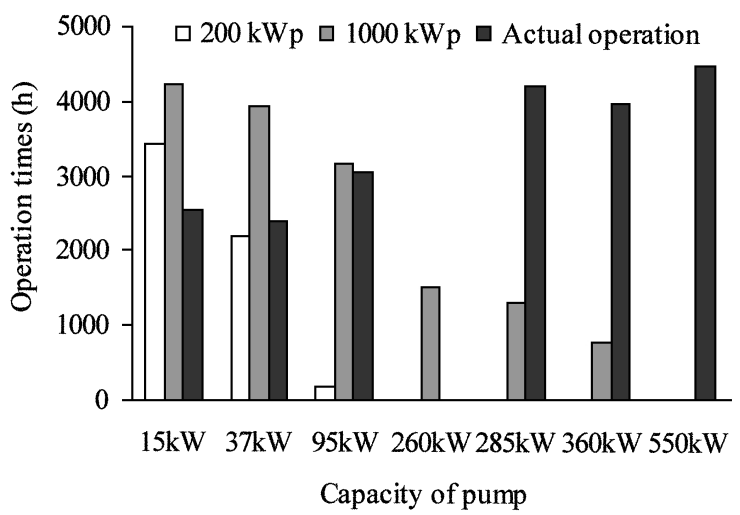

(a) One pump

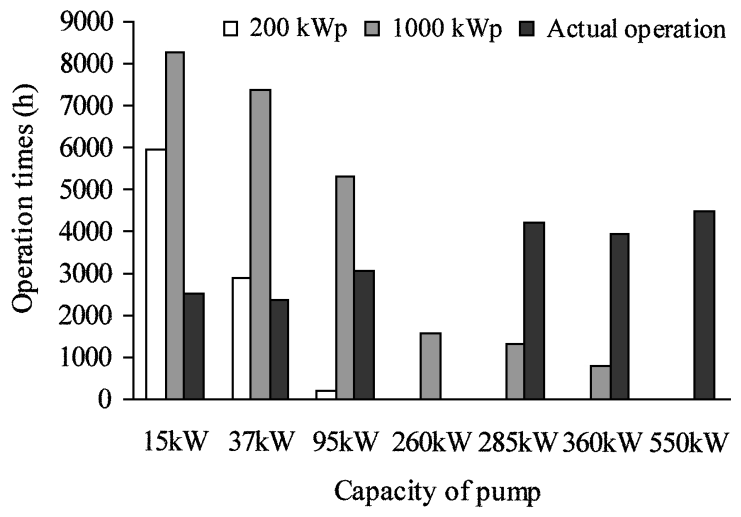

(b) Two pumps

Fig. 5. Annual operation times of pumps.

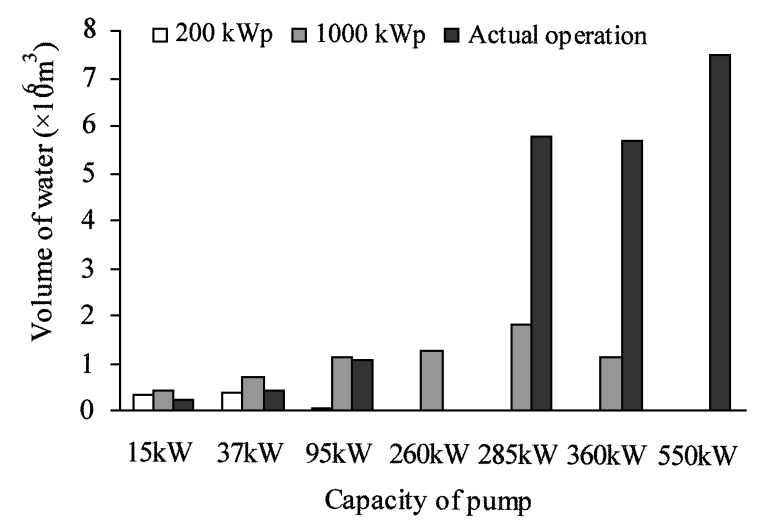

(a) One pump

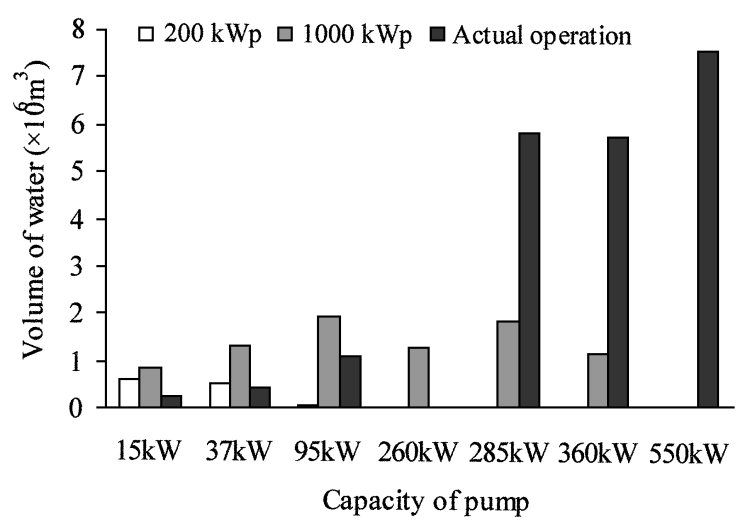

(b) Two pumps

Fig. 6. Annual volume of pumped up water.

days (Fig. 4a). On the other hand, pumps whose capacity was larger than $95 \mathrm{~kW}$ were not operated in this solar battery system.

In the $1000 \mathrm{kWp}$ solar battery systems, most pumps except for a $550 \mathrm{~kW}$ pump were operated as shown in Figures $3 \mathrm{~b}$ and $4 \mathrm{~b}$. Annual days of operation times of 8 hours was 40 days for one $285 \mathrm{~kW}$ pump, and that of operation times of 6.5 hours was 33 days for one $360 \mathrm{~kW}$ pump. When two pumps were used, larger than $95 \mathrm{~kW}$ pumps did not show the activation.

\section{Comparison of actual and estimated operation times}

Average annual operation hours of each pump was calculated using 11 years data, 1969 and form 1979 to 1988, for the $200 \mathrm{kWp}$ and $1000 \mathrm{kWp}$ solar battery systems. The annual operation hours for one pump system and two pumps system were shown in Figures 5a and 
5b, respectively. As actual pumps were operated only one set, $1000 \mathrm{kWh}$ is enough to operate $95 \mathrm{~kW}$ pump, but larger than this pumps need supplemental electricity to enough operation.

\section{Comparison of actual and estimated of pump up water}

Average annual amount of pumped up water for 11 years is shown in Figure 6. If a $1000 \mathrm{kWp}$ solar battery was used, amount of water pumped up by pumps whose capacity was smaller than $95 \mathrm{~kW}$ were completely satisfied. To cover the water pumped up by $285 \mathrm{~kW}$ pump, it is necessary to prepare over $3000 \mathrm{kWp}$ system. Economically, it is recommendable to set a $1000 \mathrm{kWp}$ battery for operating with self supplying electricity for the smaller pump system. For pumps whose capacity was lager than $260 \mathrm{~kW}$, it would be better to supply commercial electricity in addition to the electricity generated by solar batteries.

\section{Potential irrigation area by self generated elec- tricity}

Water consumption

Potential water consumption of crop field was estimated by the Penman method expressed as following equation.

$$
\begin{aligned}
E T_{p}= & \left(\frac{\Delta}{\Delta+\gamma}\right)\left(R_{n}+G\right) \\
& +\left(\frac{\gamma}{\Delta+\gamma}\right) 15.36\left(1.0+0.0062 u_{200}\right)\left(e_{z}^{0}-e_{z}\right)
\end{aligned}
$$

where, $E T_{p}$ is potential evapotranspiration $\left(\mathrm{J} / \mathrm{cm}^{2} /\right.$ day $)$, $\Delta$ is slope of saturation vapor pressure vs. temperature, $Y$ is psychometric constant, $R_{n}$ is net radiation $\left(\mathrm{J} / \mathrm{cm}^{2} /\right.$ day $), G$ is soil hear flux $\left(\mathrm{J} / \mathrm{cm}^{2} /\right.$ day $), u_{200}$ : is wind speed at the height of $200 \mathrm{~cm}(\mathrm{~km} /$ day $), e_{z}{ }^{0}$ : is saturated vapor pressure at air temperature $(\mathrm{mb})$ and $e_{z}$ is vapor pressure of air (mb).

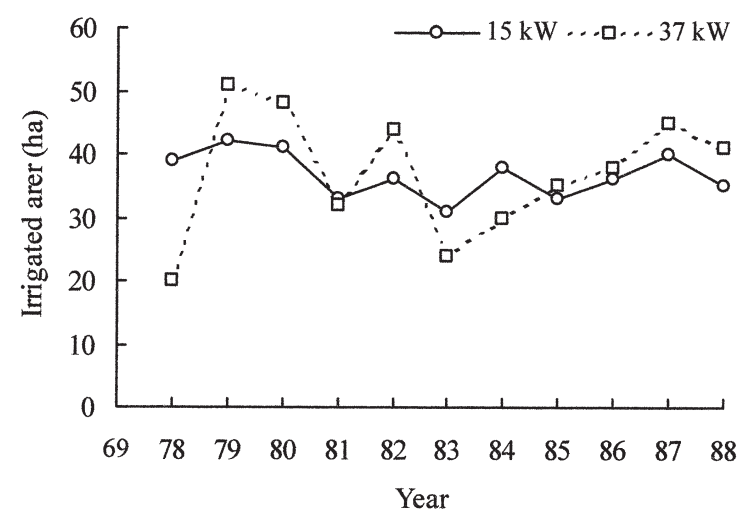

(a) $200 \mathrm{kWp}$
Daily data for 11 years provided by weather station in Ishigaki Island were used for the calculation. As the wind speed sensor was placed at $22 \mathrm{~m}$ above ground level, conversion to the $200 \mathrm{~cm}$ above ground level was conducted by using the following equation.

$$
u(\mathrm{Z})=\frac{u_{*}}{k} \ln \left[\frac{(Z-d)}{Z_{0}}\right]
$$

where, $Z$ is height of wind speed sensor, $d$ is enhanced ground level ( $=0.63 \mathrm{H}, \mathrm{H}$ : crop height), $Z_{0}$ is roughness length $(=0.13 \mathrm{H}), u_{*}$ is friction velocity and $k$ is Von Karman constant.

Actual evapotranspiration was calculated with following equation.

$$
E T=k_{c} E T_{p}
$$

where $E T$ is actual evapotranspiration and $k_{c}$ is crop coefficient. Crop coefficient of sugarcane ranges from 0.8 to 0.9 depending on the growth stage.

Potential irrigation area

For estimating the potential irrigation area, area of field supported by pumps was simulated using 11 years meteorological data in 1968 and from 1979 to 1988. There was an assumption that electricity of all pumps was supplied by the $200 \mathrm{kWp}$ or $1000 \mathrm{kWp}$ solar battery system. Total readily available soil moisture (TRAM) was specified as $8.75 \mathrm{~mm}$ referring to the field observation. Irrigation was conducted when soil moisture become less than TRAM. Input water in the field was composed of rainfall and irrigation, and output water was composed of evapotranspiration and infiltration into the deep soil. In the case of rotation of irrigation, two blocks were assumed.

Some cases were considered as follows.

Case 1: One pump system. [Fig. 7 (1)]

Case 2: One pump system with rotation block composed of two blocks. [Fig. 7 (2)]

Case 3: Two pumps system. [Fig. 7 (3)]

Case 4: Two pumps system with rotation block composed of two blocks. [Fig. 7 (4)]

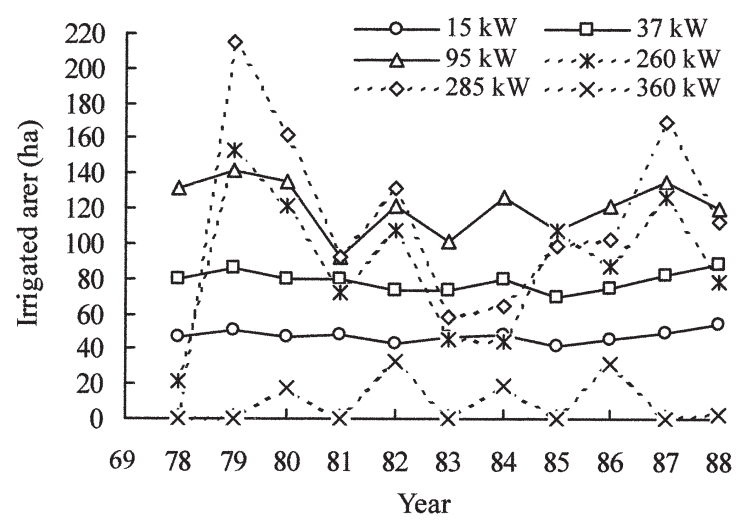

(b) $1000 \mathrm{kWp}$

(1) Case 1: One pump system, no rotation of irrigation. 


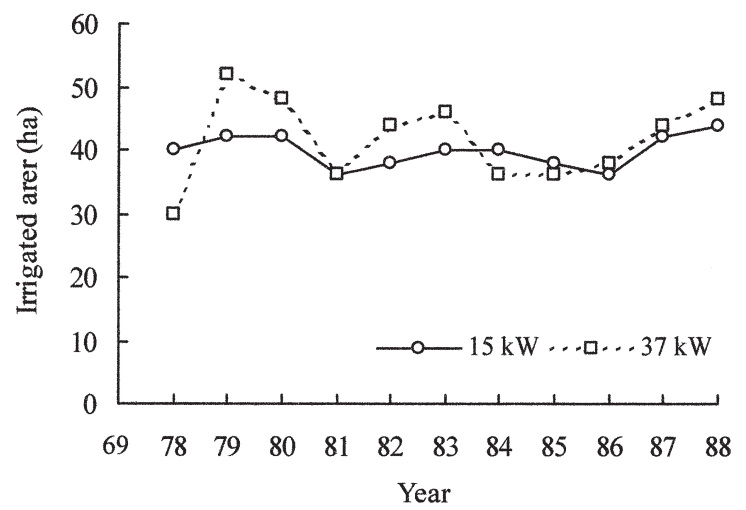

(a) $200 \mathrm{kWp}$

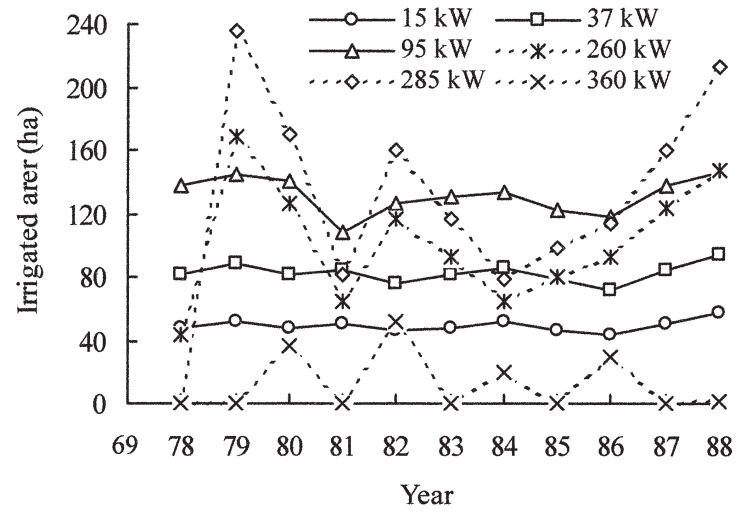

(b) $1000 \mathrm{kWp}$

(2) Case 2: One pump system, rotation of irrigation.

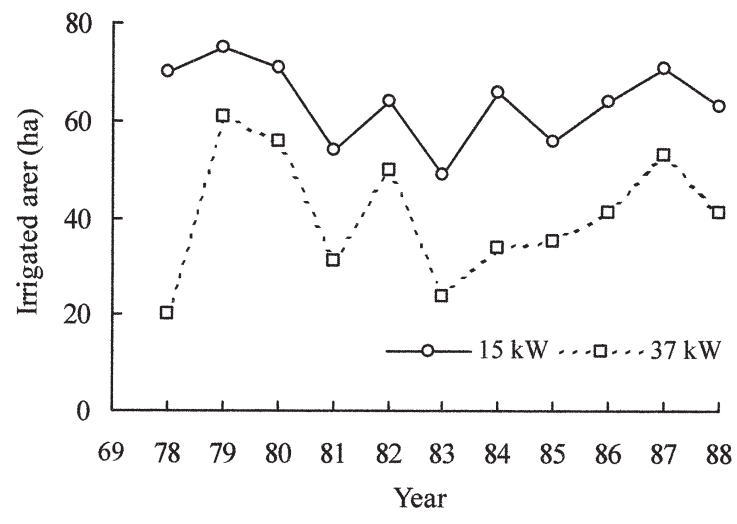

(a) $200 \mathrm{kWp}$

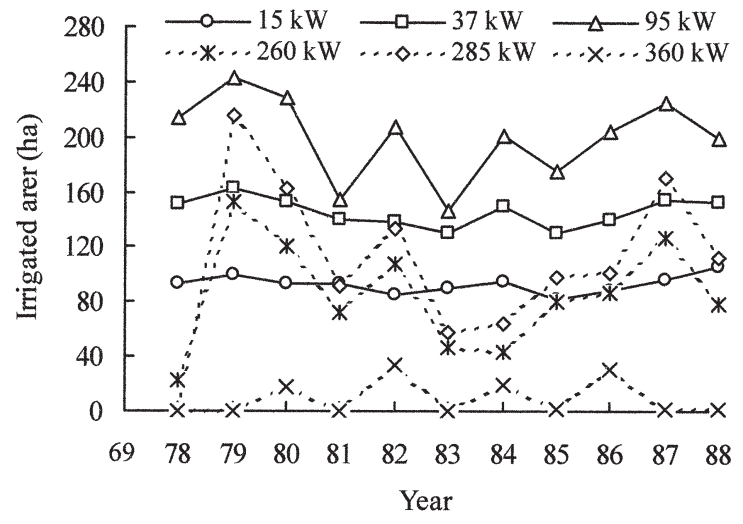

(b) $1000 \mathrm{kWp}$

(3) Case 3: Two pumps system, no rotation of irrigation.

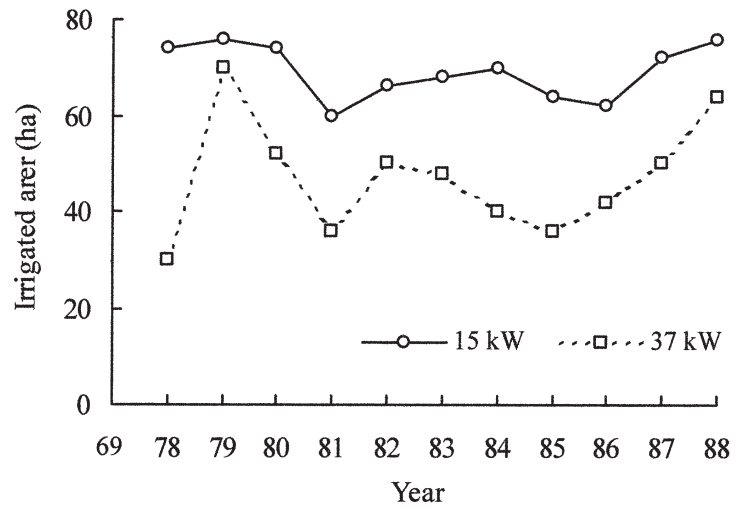

(a) $200 \mathrm{kWp}$

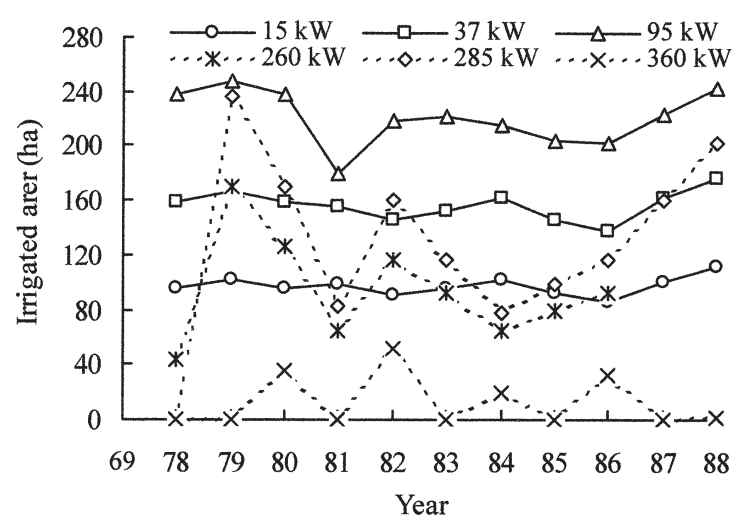

(b) $1000 \mathrm{kWp}$

(4) Case 4: Two pumps system, rotation of irrigation.

Fig. 7. Potential irrigation area supported by electricity generation system with solar battery. 
In Case 1 with a $200 \mathrm{kWp}$ solar battery, more than 30 ha field were irrigated every year by a $15 \mathrm{~kW}$ pump. A $15 \mathrm{~kW}$ pump was proper for this case as it was operated longer than other pumps as shown in Figure 5. In the Case 1 with a $1000 \mathrm{kWp}$ solar battery, constant area of field was irrigated by pumps of 15 and $37 \mathrm{~kW}$ capacity.

In Case 2 with a $200 \mathrm{kWp}$ battery, about 40 ha field were irrigated every year by a $15 \mathrm{~kW}$ pump and about 42 ha field were irrigated every year by a $37 \mathrm{~kW}$ pump. In the Case 2 with a $1000 \mathrm{kWp}$ solar battery, about 130 ha were irrigated every year constantly with a $95 \mathrm{~kW}$ pump.

In Case 3 with a $200 \mathrm{kWp}$ battery, about 60 ha field were irrigated every year by two $15 \mathrm{~kW}$ pumps. The use of $35 \mathrm{~kW}$ pumps, however, did not show the effect on the increasing the area. In the Case 2 with a $1000 \mathrm{kWp}$ battery, about 150 ha were irrigated every year constantly with two $37 \mathrm{~kW}$ pumps.

In Case 4 with a $200 \mathrm{kWp}$ battery, about 70 and 50 ha field were irrigated every year in the $15 \mathrm{~kW}$ and 37 $\mathrm{kW}$ pump systems, respectively. The $15 \mathrm{~kW}$ pump was proper as this was operated longer hours than others. In the Case 4 with a $1000 \mathrm{kWp}$ battery, about 220 ha were irrigated every year constantly with two $95 \mathrm{~kW}$ pumps.

\section{CONCLUSIONS}

There was a tendency that operation times of pumps calculated by estimated curves of solar radiation was somewhat longer than that calculated by observed curves for pumps of smaller capacity. On the other hand, for larger pumps, there was a tendency that operation times derived from observed curves exceeded the operation times derived from estimated curves. Obviously the operation times of two pumps system increased doubly comparing to the one pump system for smaller pumps with a larger electricity generation module. In the smaller electricity generation module, the operation times did not increase even if two pumps system was adopted for larger pumps. Irrigation area was slightly increased by applying rotation of irrigation.

\section{REFERENCES}

Murayama H. 1991 Gradation thesis. Irrigation and Water Utilization Kyushu Univ., pp. 1-48

Shimizu S. et al. 1990 Utilization of Natural Energy, Power Ltd., pp. 39-58 